\title{
Extracellular enolase of Candida albicans is involved in colonization of mammalian intestinal epithelium
}

\author{
Richard C. Silva ${ }^{1+}$, Ana Carolina B. Padovan ${ }^{1,2+}$, Daniel C. Pimenta ${ }^{3}$, Renata C. Ferreira $^{1,2}$, \\ Claudio V. da Silva ${ }^{1,4}$ and Marcelo R. S. Briones ${ }^{1 *}$ \\ ${ }^{1}$ Departamento de Microbiologia, Imunologia e Parasitologia, Universidade Federal de São Paulo, São Paulo, Brazil \\ 2 Disciplina de Infectologia, DMED, Universidade Federal de São Paulo, São Paulo, Brazil \\ ${ }^{3}$ Laboratório de Bioquímica e Biofísica, Instituto Butantã, São Paulo, Brazil \\ ${ }^{4}$ Universidade Federal de Uberlândia, Uberlândia, Brazil
}

\section{Edited by:}

Alfredo G. Torres, University of

Texas Medical Branch, USA

Reviewed by:

Kevin Mason, The Ohio State

University, USA

Mariana Henriques, University of

Minho, Portugal

*Correspondence:

Marcelo R. S. Briones,

Departamento de Microbiologia,

Imunologia e Parasitologia,

Universidade Federal de São Paulo

Rua Botucatu 862 ECB $3^{\circ}$ andar,

São Paulo, CEP 04023-062, Brazil

e-mail:marcelo.briones@unifesp.br

tThese authors have contributed

equally to this work.
Enolase is secreted by Candida albicans and is present in its biofilms although its extracellular function is unknown. Here we show that extracellular enolase mediates the colonization of small intestine mucosa by $C$. albicans. Assays using intestinal mucosa disks show that $C$. albicans adhesion is inhibited, in a dose dependent mode, either by pretreatment of intestinal epithelium mucosa disks with recombinant $C$. albicans enolase ( $70 \%$ at $0.5 \mathrm{mg} / \mathrm{ml}$ enolase) or by pretreatment of $C$. albicans yeasts with anti-enolase antibodies (48\% with $20 \mu \mathrm{g}$ antiserum). Also using flow cytometry, immunoblots of conditioned media and confocal microscopy we demonstrate that enolase is present in biofilms and that the extracellular enolase is not an artifact due to cell lysis, but must represent functional secretion of a stable form. This is the first direct evidence that C. albicans' extracellular enolase mediates colonization on its primary translocation site. Also, because enolase is encoded by a single locus in $C$. albicans, its dual role peptide, as glycolytic enzyme and extracellular peptide, is a remarkable example of gene sharing in fungi.

Keywords: Candida albicans, enolase, gene sharing, cell adhesion, infection

\section{INTRODUCTION}

The fungus Candida albicans is a member of the microbiota of healthy individuals. However, in immunocompromised hosts it causes infections ranging from superficial mucosal to invasive systemic, usually fatal, manifestations (Odds et al., 1988; Dalle et al., 2010). The ability to adhere to surfaces is essential for these infections, because it enables the colonization and invasion of specific host niches. The gastrointestinal (GI) tract, although not exclusive, is the main C. albicans reservoir in humans, from which systemic infections are predominantly derived by translocation (Voss et al., 1994; Nucci and Anaissie, 2001). Specialized enterocytes (Goblet cells) secrete large amounts of mucus whose diversity and rapid turnover play an important role in limiting the multiplication of Candida cells on the gastrointestinal tract (Senet, 1997; Scott and Hancock, 2000). C. albicans secretory aspartyl proteinase, that degrades intestinal mucus, may contribute to pathogenicity by facilitating the penetration of the mucus barrier and the subsequent adhesion/invasion of epithelial cells (Colina et al., 1996). The efficiency of these adhesion/invasion steps is dependent on the expression of different $C$. albicans molecules that interact with different host receptors. A variety of adhesins are involved in binding to a wide array of proteins on the host's cell surfaces, including extracellular matrix components (ECM) such as laminin, fibronectin, and fibrinogen (Senet, 1997).

Enolase is one of the most abundantly expressed cytosolic enzymes in many organisms (Holland and Holland, 1978), and considered a multifunctional protein, because it performs different functions besides its primordial role in the glycolytic pathway
(Pancholi, 2001). This is gene sharing, where an unduplicated gene acquires an additional function while maintaining its original one in the same organism (Tracy and Hedges, 2000). For example, enolase is also a heat shock protein involved in thermotolerance and growth control of Saccharomyces cerevisiae (Iida and Yahara, 1985) and a structural component of crystallins in birds, lampreys, fishes and reptiles (Piatigorsky, 2003). As observed in many other microorganisms and cells, C. albicans enolase can bind to plasminogen and plasmin. A possible mechanism for its increased ability to cross the human brain endothelial cells was proposed (Jong et al., 2003). Also, several studies have shown that enolase can mediate adhesion by interaction with extracellular matrix proteins such as fibronectin and laminin, although the underlying mechanisms are not fully understood (Carneiro et al., 2004; Esgleas et al., 2008; Castaldo et al., 2009; Donofrio et al., 2009). The enolase of C. albicans promotes a strong humoral immune response in patients with invasive candidiasis (Strockbine et al., 1984) and has been characterized as an important allergen in inhalant allergies to fungi (Ito et al., 1995). Also, it can be detected in culture medium and blood of patients (Sundstrom et al., 1994), being an important marker for invasive candidiasis (Walsh et al., 1991). It is also found on the cell surface (Eroles et al., 1997), in association with glucans in the cell wall (Angiolella et al., 1996).

Although previous studies indicate that $C$. albicans enolase is an immunodominant antigen (Angiolella et al., 1996), its precise role in C. albicans pathogenesis is still unknown. Here we show that pretreatment of GI epithelia with enolase blocks adhesion. Incubation of $C$. albicans with anti-enolase antibodies has a 
similar effect. We also demonstrate that enolase is secreted to the extracellular medium and biofilms. Our data also show that extracellular enolase derived from simple fungal lysis has a very short half life outside the cells suggesting that the proper extracellular form is not an artifact or an accidental leakage but it is actively secreted. Here we provide for the first time a potential role for the extracellular enolase in the gastrointestinal mucosae, the major translocation site of C. albicans. Our findings also suggest a novel example of gene sharing in fungi because enolase is encoded by a single locus in C. albicans. From our data we predict that enolase ligands might be present on the cell surface of the intestinal epithelia or in the thick and complex structure of mucus covering its surface.

\section{MATERIALS AND METHODS MICROORGANISMS AND GROWTH CONDITIONS}

Unless otherwise stated, C. albicans strain SC5314, kindly provided by Dr. A. Mitchell-Carnegie Mellon University, USA; C. albicans clinical isolate L296 (high biofilm-forming strain), kindly provided by Dr. Arnaldo L. Colombo-UNIFESP, LEMI, Brazil; Saccharomyces cerevisiae strain S288C, kindly provided by Dr. Beatriz A. Castilho-UNIFESP, Brazil and the reference $C$. albicans strain ATCC90029 (low biofilm-forming strain), were grown in YPD medium (1\% yeast extract, 2\% peptone, 2\% dextrose) overnight with rotary agitation at $30^{\circ} \mathrm{C}$. Cells were counted in a hemacytometer (Hirschmann EM Techcolor) and adjusted to the desired concentration immediately before the experiments. To produce hyphae, $C$. albicans yeasts were diluted to $1.0 \times 10^{7}$ cells $/ \mathrm{ml}$ in fetal bovine serum containing $5 \mathrm{mg} / \mathrm{ml}$ dextrose and incubated at $37^{\circ} \mathrm{C}$ with agitation for $3 \mathrm{~h}$. Escherichia coli strain DH5- $\alpha$ was used for plasmid transformation. Strain BL21 (DE3) was used for recombinant protein expression. E. coli strains were grown overnight in LB medium supplemented with $100 \mu \mathrm{g} / \mathrm{ml}$ ampicilin or $15 \mu \mathrm{g} / \mathrm{ml}$ kanamicyn at $37^{\circ} \mathrm{C}$ with constant agitation.

\section{EXPRESSION AND PURIFICATION OF RECOMBINANT ENOLASE IN E. coli}

The complete coding region of $C$. albicans enolase gene was PCR amplified from genomic DNA with the following oligonucleotides: EnoexpresF:(5'-CGGGATCCATGTCTTACG CCACTAAAATC-3 $\left.3^{\prime}\right)$ and EnoexpresR: (5'-ATAGTTTAGCGGC CGCTTACAATTGAGAAGCCTTT-3'). The insert was subcloned between Not I and Bam $\mathrm{HI}$ restriction sites in plasmid pET-28a $(+)$ (Novagen), in fusion with a Histidine tag at the N-terminal portion according to (Sambrook et al., 1989). This construction was transformed into E. coli BL21 (DE3). An overnight culture was inoculated into LB medium containing Kanamycin $(15 \mu \mathrm{g} / \mathrm{mL})$ and C. albicans enolase expression was then induced with $1 \mathrm{mM}$ isopropyl- $\beta$-D-thiogalactopyranoside (IPTG) at $37^{\circ} \mathrm{C}$ for $2 \mathrm{~h}$. After centrifugation, cells were lysed and the recombinant protein $\left(\mathrm{His}_{6}\right.$-enolase) was purified under native conditions in pre-packed Ni-sepharose columns (Clontech) according to the manufacturer's instructions. The eluted protein was dialyzed for $36 \mathrm{~h}$ at $15^{\circ} \mathrm{C}$ against phosphate-buffered-saline (PBS) $\mathrm{pH}$ 7.6. Protein concentration was determined with the Bradford assay (Bradford, 1976) and by SDS-PAGE analyses. To assess the purity of the recombinant protein, samples were analyzed by Coomassie blue and silver nitrate staining SDS-polyacrylamide gel electrophoresis.

\section{GENERATION OF POLYCLONAL SERA AGAINST His $\mathbf{6}_{\mathbf{6}}$-enolase}

Purified $\mathrm{His}_{6}$ - enolase was used to generate specific immune rabbit polyclonal sera. One hundred and fifty microgram of the protein with complete and incomplete Freund's adjuvant (Sigma) for the first and the other two doses respectively, at 20-days intervals, was subcutaneously injected in 2 adult female New Zealand white rabbits. To obtain the pre-immune sera, aliquots of blood were collected before the first immunization. Whole blood was collected 55 days after the first immunization. Sera were obtained by incubating the blood for $30 \mathrm{~min}$ at $37^{\circ} \mathrm{C}$ and overnight at $4^{\circ} \mathrm{C}$, followed by centrifugation under $1000 \mathrm{rpm}$ for $15 \mathrm{~min}$ at $4^{\circ} \mathrm{C}$. All sera were stored at $-80^{\circ} \mathrm{C}$.

\section{PREPARATION OF CELL LYSATES}

$5 \times 10^{8}$ yeasts were resuspended in lysis solution $(20 \mathrm{mM}$ Tris $\mathrm{pH}$ 8.0, $2 \mathrm{mM} \mathrm{MgCl}_{2}, 2 \mathrm{mM}$ EGTA and $150 \mathrm{mM} \mathrm{NaCl}$ ) with protease inhibitors ( $1 \mathrm{mM}$ phenylmethylsufonyl fluoride (PMSF), $2 \mathrm{mM}$ benzamidin, $1 \mu \mathrm{g} / \mathrm{ml}$ leupeptin, $10 \mu \mathrm{g} / \mathrm{ml}$ pepstatin $\mathrm{A}, 4 \mu \mathrm{g} / \mathrm{ml}$ aprotinin, and $1 \mu \mathrm{g} / \mathrm{ml}$ antipain) and phosphatase inhibitors (10 mM Sodium Pyrophosphate and $1 \mathrm{mM}$ Sodium Fluoride). Cell suspensions were vortexed and lysis was done by sequential freezing/thawing. After centrifugation at 13,000 rpm, for $15 \mathrm{~min}$ at $4^{\circ} \mathrm{C}$, the supernatant (soluble fraction) was separated from the cellular debris and stored at $-80^{\circ} \mathrm{C}$ prior to each use. For spent medium extraction, C. albicans SC5314 cultures in minimum and YPD media were grown at $37^{\circ} \mathrm{C}$ for $1-3$ days. After incubation, $5 \mathrm{ml}$ of media were separated from cells by centrifugation, filtered sterilized, concentrated $500 \times$ and frozen at $-80^{\circ} \mathrm{C}$. E. coli cell lysates of $10^{7}$ cells were prepared by sequential freezing/boiling procedures and the supernatant was separated from the cellular debris by centrifugation at $13,000 \mathrm{rpm}$ for $5 \mathrm{~min}$ at $4^{\circ} \mathrm{C}$, and stored at $-80^{\circ} \mathrm{C}$.

\section{BIOFILM FORMATION AND PROTEIN MATRIX SEPARATION}

C. albicans SC5314 biofilm was induced according to the protocol described elsewhere (Hawser and Douglas, 1994), with minor modifications. Biofilms were grown on $150 \mathrm{~mm}^{2}$ culture bottles, using minimal medium $(0.67 \% \mathrm{YNB}$, Difco) supplemented with $50 \mathrm{mM}$ glucose. Biofims were allowed to grow during $66 \mathrm{~h}$, with medium replacement every $24 \mathrm{~h}$. The spent medium was removed and biofilms were washed twice with $20 \mathrm{ml}$ of cold PBS to remove non-adherent cells. $10 \mathrm{ml}$ of cold PBS were added into each bottle and using cell scrappers, all biofilms and cells were detached from the bottles. The biofilm suspension was vigorously vortexed to disassemble cells from biofilm matrix, which were separated by centrifugation at $4000 \mathrm{rpm}, 8 \mathrm{~min}, 4^{\circ} \mathrm{C}$. Biofilm matrix supernatant was then filtered $(0.22 \mu \mathrm{m}$ filters, TPP), concentrated 500 times using Centricon Plus-20 (5000 mW-Millipore) and stored at $-80^{\circ} \mathrm{C}$.

\section{WESTERN BLOT}

Cell lysates and proteins were resuspended in $4 \times$ Laemmli buffer, boiled for $5 \mathrm{~min}$, separated by SDS-PAGE (Laemmli, 1970) and transferred to poly (vinylidene difluoride) membranes (GE 
Healthcare) (Towbin et al., 1979). Membranes were blocked overnight at $4^{\circ} \mathrm{C}$ with 5\% non-fat dry milk in PBS-0.1\% tween 20 and probed with: Pre-immune rabbit serum (1:500 in PBS); antiHis $_{6}$-enolase (1:2000 in PBS); anti-His 6 -tag antibody-Santa Cruz Biotechnology (1:1000 in PBS). Membranes were then incubated with anti-rabbit IgG or anti-mouse IgG secondary antibodies (Sigma) at 1:1000 for $1 \mathrm{~h}$ in an orbital shaker. Detection was performed with the ECL-PLUS (GE Healthcare) according to the manufacturer's suggestions.

\section{ENOLASE DECAY ASSAY}

C. albicans SC5314 was grown in minimum medium at $37^{\circ} \mathrm{C}$ until the stationary phase. The culture was separated into two batches. The first batch was then separated again. One flask was maintained at room temperature and the other at $37^{\circ} \mathrm{C}$ without shaking for $5 \mathrm{~h}$. The second batch was rapidly centrifuged to separate the cells from conditioned medium, filtered and then separated again. One flask was maintained at room temperature and the other at $37^{\circ} \mathrm{C}$ without shaking for $5 \mathrm{~h}$. Aliquots of $5 \mathrm{ml}$ were removed in different time points: $0 \mathrm{~min}, 30 \mathrm{~min}, 1,2,3,4$, and $5 \mathrm{~h}$, concentrated 500 times (to $10 \mu \mathrm{l}$ ) and stored at $-80^{\circ} \mathrm{C}$.

\section{FLOW CYTOMETRY}

C. albicans SC5314 was grown in YPD medium, overnight, at $37^{\circ} \mathrm{C}$ and $200 \mathrm{rpm}$. Two aliquots of $10^{7}$ yeasts were separated. The first aliquot was fixed in $3.5 \%$ formaldehyde for $1 \mathrm{~h}$, washed in PBS and incubated overnight with anti $\mathrm{His}_{6}$-enolase (diluted 1:80 in PGN $+1 \%$ saponin) (permeabilized cells). The second aliquot was first incubated with anti $\mathrm{His}_{6}$-enolase without saponin and then was fixed (non-permeabilized). After consecutive washes in PBS, cells were incubated with anti-rabbit IgG marked with fluorescein (FITC) (diluted 1:100 in PBS) for one $1 \mathrm{~h}$, at room temperature. After two washes, the number of yeasts was estimated with a fluorescent cytometer Becton-Dickinson, counting $10^{4}$ cells. As a control, permeabilized and non-permeabilized cells were incubated with pre-immune rabbit serum. For the enolase uptake assay, a culture of C. albicans SC5314 was processed as described above. Five aliquots of $2 \times 10^{4}$ cells were separated. The first aliquot was incubated overnight at $4^{\circ} \mathrm{C}$ with the elution buffer of the recombinant protein purification and the other four aliquots were incubated with different concentrations of $\mathrm{His}_{6}$ enolase: $1.25,2.5,5$, and $10 \mu \mathrm{g}$. After washes with PBS, cells were fixed with $3.5 \%$ paraformaldehyde for $1 \mathrm{~h}$. Then, cells were incubated with anti-His 6 (diluted 1:20 in PGN) for $1 \mathrm{~h}$, washed and incubated with anti-rabbit-IgG labeled with FITC (diluted 1:50 in PBS). As control, the recombinant enolase was coupled to latex beads ( $100 \mu \mathrm{g}$ of $\mathrm{His}_{6}$-enolase to $10^{8}$ beads) and incubated in coupling buffer $(200 \mathrm{mM}$ sodium carbonate, $500 \mathrm{mM}$ sodium chloride, $\mathrm{pH} 8.5$ ) overnight, at $37^{\circ} \mathrm{C}$, with agitation. Beads were subsequently washed and blocked with BSA solution in PBS $(20 \mathrm{mg} / \mathrm{ml})$ and then incubated with anti-His 6 (diluted 1:20 in PGN) for $1 \mathrm{~h}$. After this period, they were washed and incubated with anti-mouse IgG labeled with FITC (diluted 1:50 in PGN). After two washes cells were analyzed in a Becton-Dickinson flow cytometer (10,000 events).

\section{IMMUNOFLUORESCENCE MICROSCOPY}

C. albicans were centrifuged, washed with PBS and fixed with $3.5 \%$ formaldehyde in PBS for $1 \mathrm{~h}$. After incubation, cells were washed at least five times with PBS and then $10 \mu 1$ were dripped on to glass slides to dry at room temperature. For biofilm formation, glass slides were coated with poly-lysine $(10 \mathrm{mg} / \mathrm{ml})$ (Sigma), dried and the biofilm was formed according to the protocol previously described. Slides containing yeasts, hyphae and biofilm were permeabilized with $1 \%$ saponin (BDH, Amersham, $\mathrm{UK})$ in $\mathrm{PGN}\left(0.2 \%\right.$ gelatin, $0.1 \% \mathrm{NaN}_{3}$ in PBS) or incubated only with PGN for blocking (non-permeabilized cells) for $15 \mathrm{~min}$. The coverslips were incubated with anti-His 6 -enolase (diluted 1:80 in PGN or PGN + saponin) overnight at $4^{\circ} \mathrm{C}$ and washed with PBS. They were subsequently incubated with anti-rabbit-IgG conjugated with Cy3 (Sigma) diluted 1:100 in calcofluor white $(10 \mathrm{mg} / \mathrm{ml})$ for $1 \mathrm{~h}$, in the dark. After washing with PBS, coverslips were mounted in glycerol buffered with $100 \mathrm{mM}$ Tris $\mathrm{pH}$ 8.6 and $0.1 \%$ p-phenylenediamine. Slides were examined under a confocal microscope (BioRad 1024-UV) coupled to a Zeiss Axiovert 100 microscope. Alternatively, images were acquired in an epifluorescence microscope.

\section{ADHESION ASSAYS}

The adhesion assays were based on a modification of the protocol previously described by (Segal and Sandovskylosica, 1995). Five week-old male Balb/c mice were purchased from University of São Paulo - USP, Brazil. Experiments were performed in accordance with guidelines for animal use and care of the Federal University of São Paulo-UNIFESP and approved by the Ethics Committee in Research. Mice were maintained in pathogen free conditions and aged 8-12 weeks for the experiments. Mouse integral intestine was aseptically removed from sacrificed animals and a cut of approximately 0.4 inches was done after the end of the stomach and before the caecum. The small intestine (duodenum, jejunum, and ileum) was cut longitudinally, rinsed once in sterile PBS to remove aggregates and opened on a flat surface. Mice intestinal tissue disks ( $6 \mathrm{~mm}$ in diameter) were obtained with a sterile metal punch. Inhibition of $C$. albicans adhesion to mouse intestinal disks coated with recombinant enolase was performed as follows: disks were added to eppendorf tubes containing increasing concentrations of $\mathrm{His}_{6}$-enolase to a final volume of $1 \mathrm{ml}$ in PBS. These tubes were then incubated for $2 \mathrm{~h}$ at $37^{\circ} \mathrm{C}$ in an orbital shaker. Disks were rinsed twice in PBS, added to eppendorf tubes containing $2.5 \times 10^{6}$ C. albicans in PBS and incubated for $2 \mathrm{~h}$ at $37^{\circ} \mathrm{C}$. Disks were rinsed 5 times to remove non adherent cells, homogenized and eluted in $1 \mathrm{ml}$ of PBS. Pre-coated C. albicans adhesion assays were performed by preincubating $5.2 \times 10^{6}$ C. albicans yeasts with different concentrations of purified anti $\mathrm{His}_{6}$-enolase for $2 \mathrm{~h}$ at $37^{\circ} \mathrm{C}$. Cells were centrifuged at $3000 \mathrm{~g}$ for $3 \mathrm{~min}$ at $4^{\circ} \mathrm{C}$, washed 3 times and eluted. Disks were added to cell suspensions and processed as previously described. All elutions were serially diluted and plated on YPD medium containing $34 \mu \mathrm{g}$ of chloramphenicol/ml. Plates were incubated for $48 \mathrm{~h}$ at $30^{\circ} \mathrm{C}$, and the number of attached microorganisms per tissue disk was estimated by counting $C$. albicans colony forming units (cfu).

\section{RESULTS \\ POTENTIAL ROLE OF BIOFILM ENOLASE}

The intracellular role of enolase as a glycolytic pathway enzyme is widely known. To investigate its potential extracellular role, 
suggested by its presence in the biofilm matrix, we produced a recombinant C. albicans enolase (Figure 1) and an anti-His $6^{-}$ enolase polyclonal rabbit serum. We found that native enolase can be detected in the biofilm matrix of C. albicans SC5314 and in cell lysates of three different $C$. albicans strains including the SC5314, one clinical isolate identified as a high biofilm producer (L296) and a reference strain that is a low biofilm producer (ATCC90029), used as control (Padovan et al., 2009) (Figure 1C). Only one band was observed in the biofilm matrix and also the homologous enolase in the cell lysate of $S$. cerevisiae S288C. A weaker signal was observed after 3 days in YPD medium (Figure 1C).

\section{ENOLASE IS PRESENT ON THE CELL SURFACE}

Since it has been reported that enolase is present on the cell surface of yeasts (Pancholi, 2001), we tested the ability of the anti $\mathrm{His}_{6}$-enolase polyclonal rabbit serum to detect cell surface enolase in biofilm-forming cells. Flow cytometry data (Figure 2A) showed that enolase could be detected on the surface of $14 \%$ nonpermeabilized yeasts cells, while in permeabilized cells; enolase

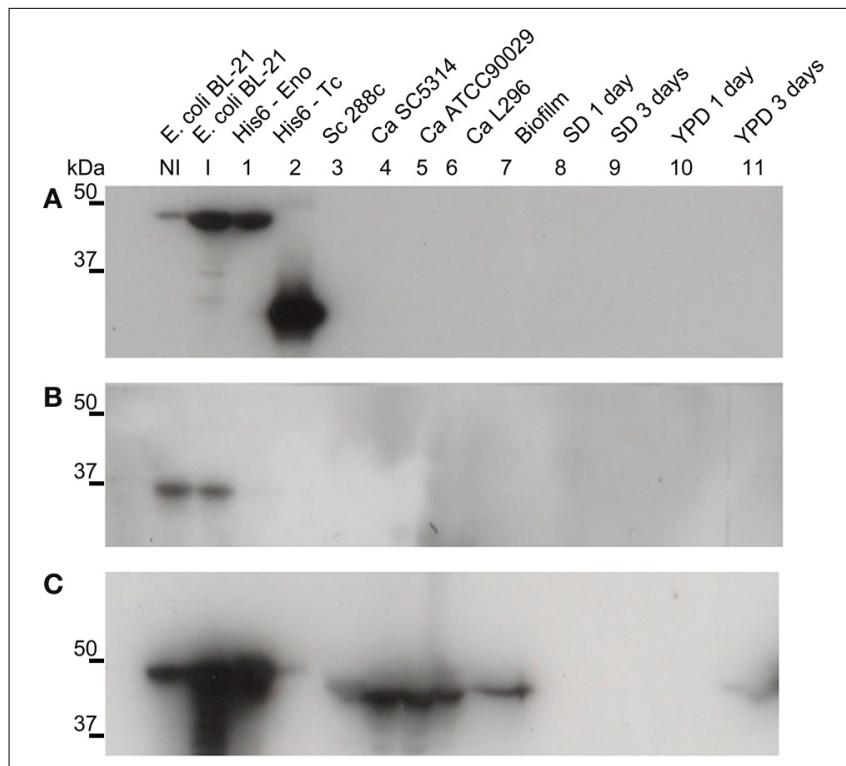

FIGURE 1 | Native enolase is recognized in C. albicans cell lysates, biofilm and supernatant of conditioned rich medium. Western blots of enolase in biofilm and cell lysates of different $C$. albicans strains, according to: NI, non-induced E. coli BL-21 lysate; I, E. coli BL-21 expression induced for $2 \mathrm{~h}$ at $37^{\circ} \mathrm{C}$ lysate; 1 , recombinant His6-enolase; 2, His6-T. cruzi $30 \mathrm{kDa}$ protein used as control; 3 , S. cerevisiae $288 \mathrm{c}$ cell lysate; 4 , C. albicans SC5314 cell lysate; 5, C. albicans ATCC90029 cell lysate, 6, C. albicans L296 cell lysate; 7, C. albicans SC5314 biofilm matrix concentrated 500 times; $C$. albicans SC5314-conditioned medium are respectively: 8, minimal medium with $24 \mathrm{~h}$ growth; 9, minimal medium with $72 \mathrm{~h}$ growth; 10, YPD with $24 \mathrm{~h}$ growth; and 11, YPD with $72 \mathrm{~h}$ growth. (A) anti-His 6 antibody (dilution 1:1000), shows the recognition of the recombinant protein of His $_{6}-$ T. cruzi and the His $_{6}$-enolase, confirming its proper purification; (B) pre-immune rabbit serum (1:500), showing no recognition of fungal proteins and recognition of a non-specific low molecular weight band (below $37 \mathrm{kDa}$ ) within the E. coli extracts; and (C) anti His6-enolase (1:2000), showing recognition of the recombinant enolase and native protein in biofilms, cell lysates and spent medium. was detected in $40 \%$ (Figure 2B). The growth conditions of cells used in this experiment (see Flow cytometry) might have induced the formation of germ-tubes and pseudo-hyphae, possibly explaining the flatline shift in fluorescence observed in Figures $\mathbf{2 A , B}$. To verify whether cells in the biofilm also had enolase on their surface, immunofluorescence microscopy images of yeasts and hyphae were compared with biofilms (Figure 3). Figures 3A-D show that enolase was not recognized by the preimmune serum. Figures $\mathbf{3 E}-\mathbf{H}$ show enolase covering the cell surface of non-permeabilized yeasts. Diffused and stronger labeling was observed in permeabilized cells (Figure 3K) although several cells were not labeled. Figures $3 \mathbf{M}, \mathbf{N}$ showed strong enolase signal in permeabilized biofilm-forming cells, both in yeasts attached to the slide, at the basal layer, as in hyphae and buds at the upper part of the biofilm. Non-permeabilized biofilm-forming cells exhibited less enolase signal on their surface (Figures 30,P). Strikingly, in non-permeabilized biofilm-forming cells, the co-localization of enolase with calcofluor occurred in a few cells. These data support previous findings that enolase is present on the cell surface of $C$. albicans yeasts and indicate for the first time that enolase is also present on the surface of hyphae and biofilm-forming cells (yeasts and hyphae).

\section{BIOFILM ENOLASE IS NOT DERIVED FROM LEAKAGE OF DEAD CELLS}

It could be argued that the presence of enolase in the biofilm matrix is a consequence of cytoplasm leakage of dead cells at the bottom layers of the biofilm, and therefore there would be no specific function for enolase in the biofilm matrix. To test whether native enolase could be detected in stationary cultures,

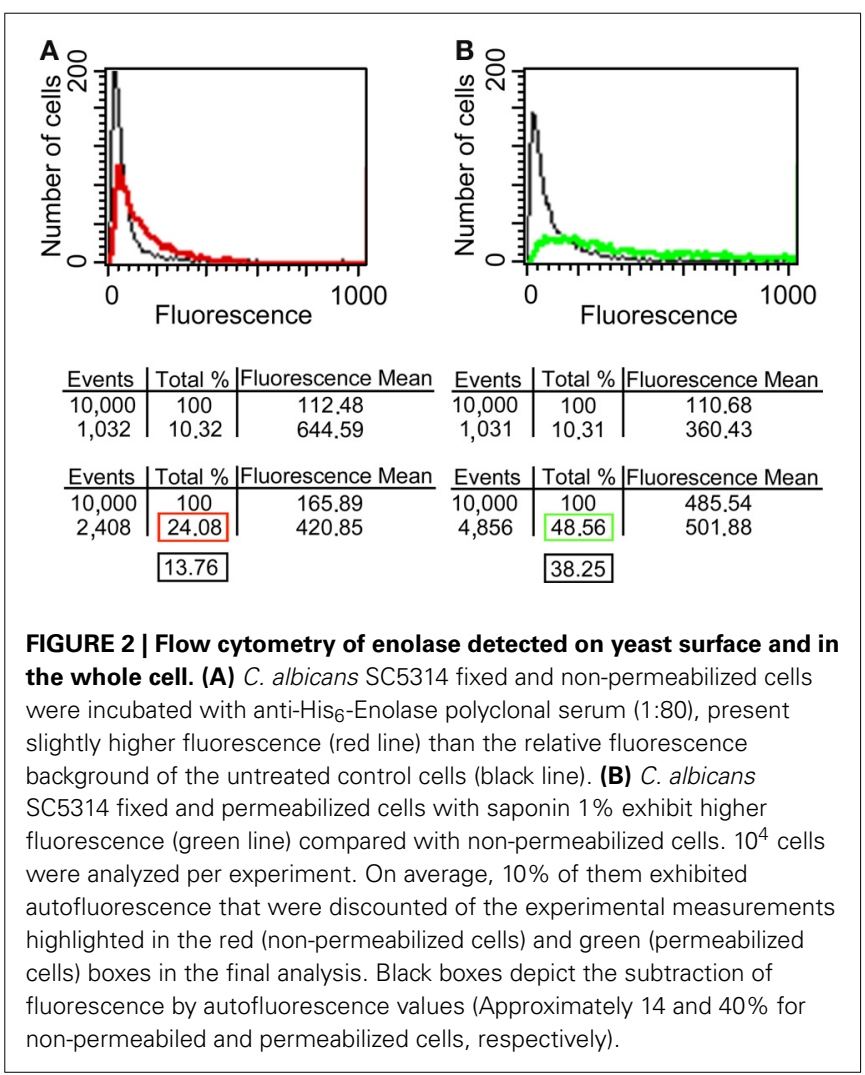



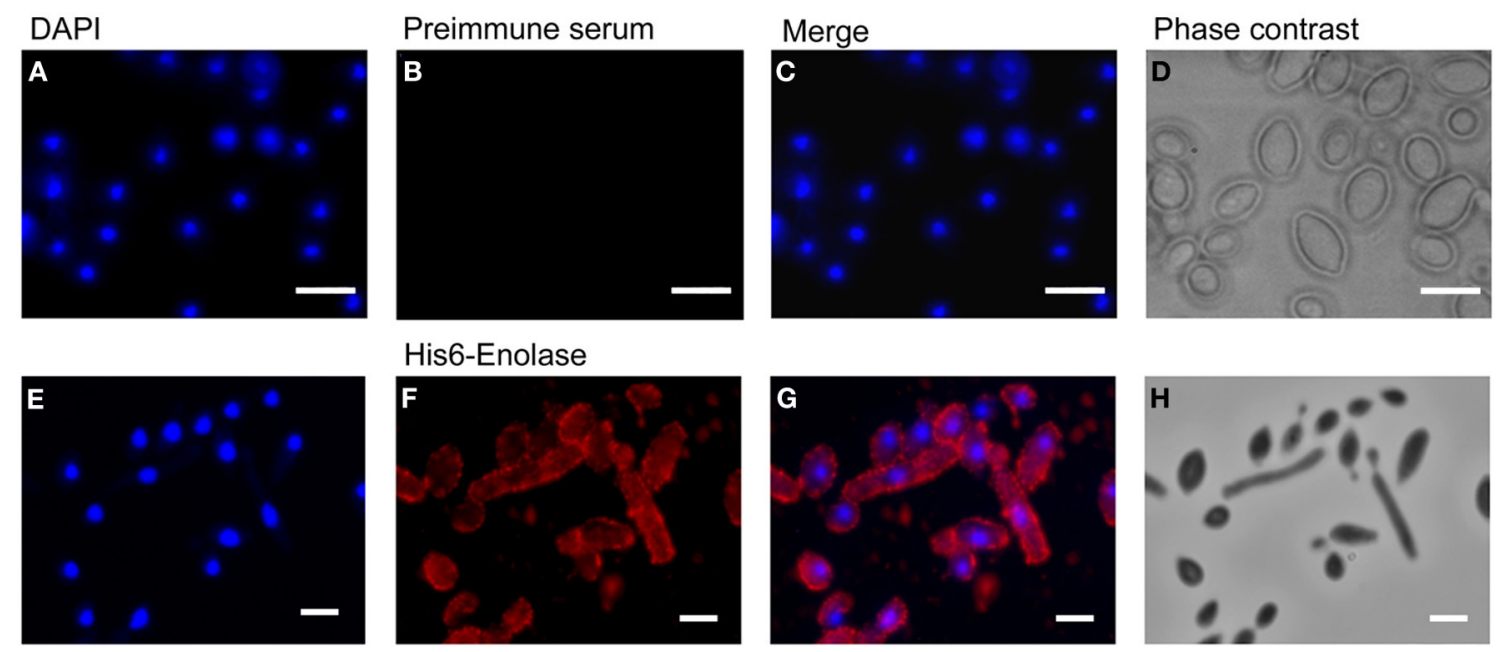

\section{His6-Enolase}
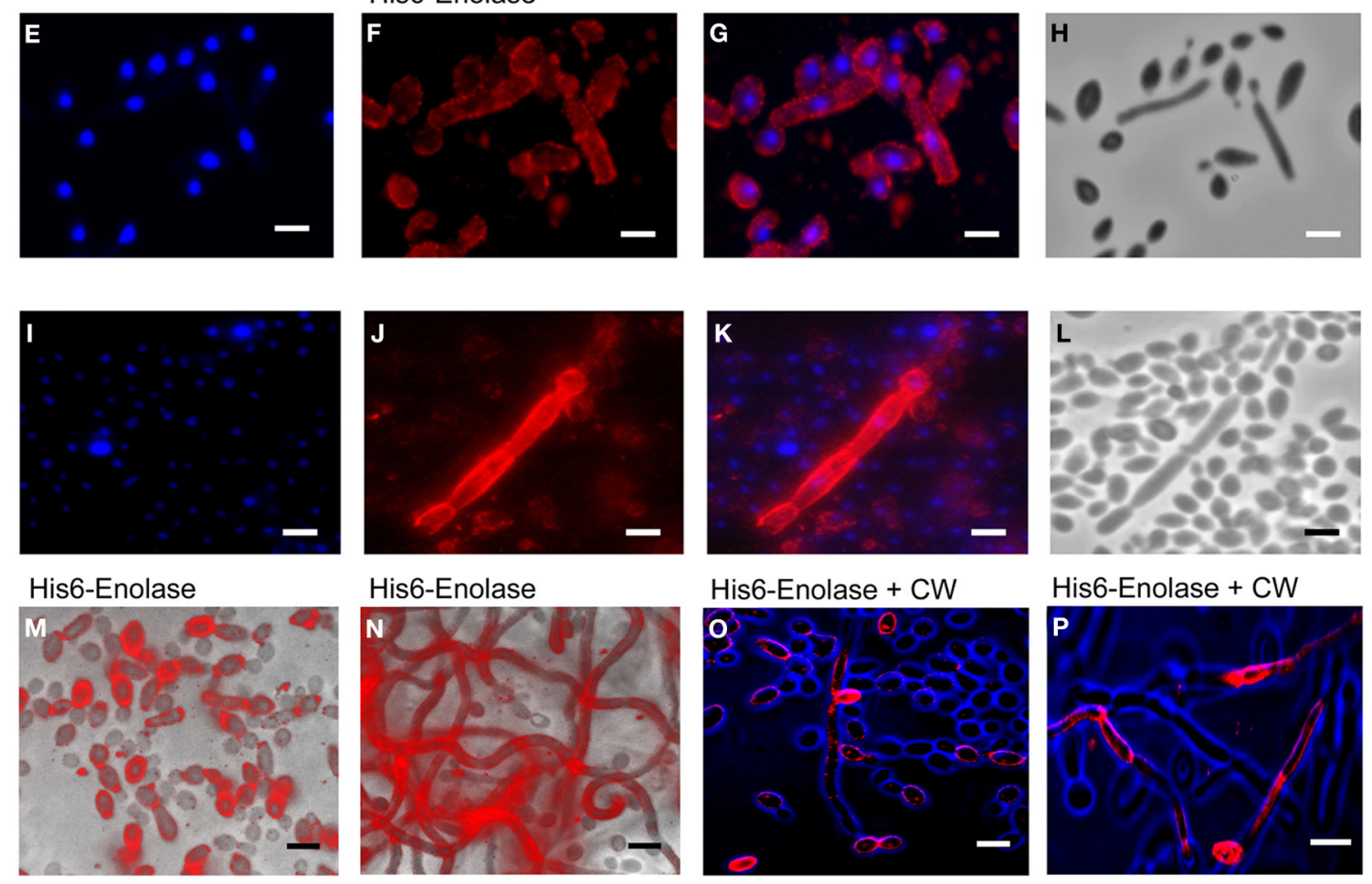

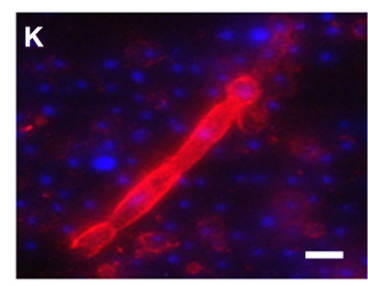

His6-Enolase + CW
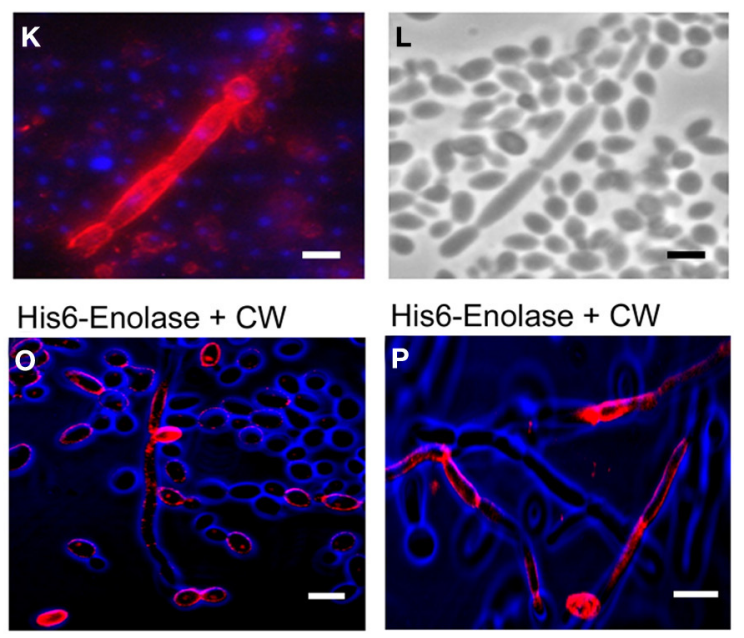

His6-Enolase + CW

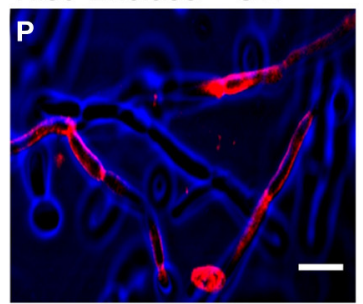

FIGURE 3 | Immunofluorescence of native enolase detected in yeasts, hyphae and biofilm-forming cells of $C$. albicans SC5314.

Immunofluorescence of yeasts permeabilized with saponin 1\%: (A) DAPI (1:2000); (B) Pre-immune serum (1:80); (C) Merged images and (D) Phase contrast image. Immunofluorescence of non-permeabilized yeast and filaments cells: (E) DAPI (1:2000); (F) anti His ${ }_{6}$-enolase polyclonal serum (1:80); (G) Merged images and (H) Phase contrast image. Filaments permeabilized with saponin 1\%: (I) DAPI (1:2000); (J) anti His6-enolase polyclonal serum (1:80); (K) Merged images and (L) Phase contrast image. Presence of enolase in biofilm cells permeabilized with saponin $1 \%$ and incubated with anti $\mathrm{His}_{6}$-enolase polyclonal serum (1:80): (M) immunofluorescence microscopy overlaid with phase contrast of the bottom part of the biofilm enriched with yeasts; (N) immunofluorescence microscopy overlaid with phase contrast of the upper part of the biofilm enriched with hyphae cells. Immunofluorescence microscopy images merge of enolase in non permeabilized biofilm cells stained with calcofluor white (CW) (1:200) and incubated with anti His 6 -enolase polyclonal serum (1:80): (0) bottom part of the biofilm with budding yeasts highly covered with enolase; (P) upper part of the biofilm enriched with hyphae. Bars: $10 \mu \mathrm{m}$.
C. albicans SC5314 was grown in minimal medium until reaching the stationary phase and aliquots of the culture medium with and without cells were taken from $0.5,1,2,3,4$, and $5 \mathrm{~h}$ to check for the presence of native enolase. A decay in native enolase levels was observed at room temperature, with or without cells (Figure 4A), while a much faster decay was observed at $37^{\circ} \mathrm{C}$ at $30 \mathrm{~min}$, especially in the cell-free conditioned medium (Figure 4B). To test whether cytosolic proteins could be detected in the biofilm due to cell lysis, we checked for the presence of Sui2p (eIF2 $\alpha$-The alpha subunit of the eukaryotic translation initiation factor 2), a cytoplasmic protein of S. cerevisiae. The S. cerevisiae Sui2p has $84 \%$ of similarity and 70\% identity with its C. albicans homolog, CaSui2p (orf19.6213). We detected Sui2p and CaSui2p in cell extracts of $S$. cerevisiae and C. albicans, respectively, while in conditioned media it was weakly detected and not detected at all in the biofilm matrix (Data not shown).

\section{SHORT HALF-LIFE OF DEAD CELL LEAKED ENOLASE IS NOT EXPLAINED BY REUPTAKE}

Because enolase was detected on the cell surface of planktonic yeasts and hyphae and on biofilm forming cells, the enolase decay could also be explained by the enolase uptake from the external medium to the cell wall. To test this hypothesis, cultures of $C$. albicans SC5314 were incubated with 4 different concentrations 


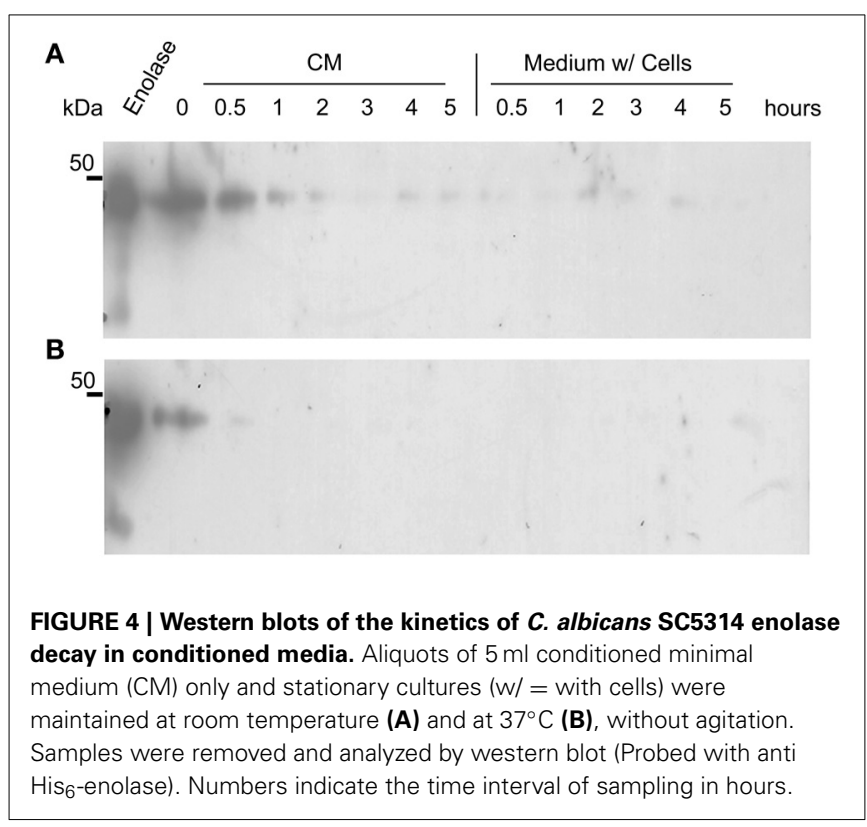

of $\mathrm{His}_{6}$-enolase and its presence on the cell surface of yeasts was assessed by flow cytometry. Figure 5 shows that there was no recognition of the recombinant enolase on the surface of C. albicans cells in all the concentrations tested $(1.25-10 \mu \mathrm{g})$, as opposed to $\mathrm{His}_{6}$-enolase coated beads. These data suggest that enolase present on the cell surface is not a product of protein uptake from cell debris lysis.

Taken together the results above suggest that enolase in the biofilm matrix is not a product of cell lysis because it would be rapidly degraded at $37^{\circ} \mathrm{C}$ as occurred in yeast cell cultures (Figure 4B). Therefore enolase might be functionally secreted to the extracellular environment such as biofilms and to the cell surface where it is stable. These results also indicate that the presence of enolase on the cell surface is not a result of protein uptake from cell debris lysis.

\section{BLOCKING OF CELL SURFACE ENOLASE WITH ANTI-ENOLASE INHIBITS C. albicans ADHESION TO MICE GI TISSUE DISKS}

To investigate the role of cell surface enolase in adhesion, we first checked whether $C$. albicans yeasts preferentially associates with specific parts of mice small intestine in vitro. There was no difference in the number of yeasts adhering to disks obtained from three equal portions (proximal, medial and distal third parts) of small intestine tissues (Figure S1 supplemental). Therefore, we employed disks prepared from the whole small intestine in all our assays. C. albicans yeasts were pre-incubated with different concentrations of affinity-purified rabbit anti-serum and then incubated with mice GI tissue disks. There was no difference in the number of yeasts per tissue disks when C. albicans was blocked with the pre-immune serum or with the anti $\mathrm{His}_{6}-\mathrm{CaYlr39 \textrm {cp }}$ (an antibody against the intracellular protein CaYlr339cp), used as a negative control. On the other hand, blocking $C$. albicans with 10 and $20 \mu \mathrm{g}$ of anti $\mathrm{His}_{6}$-enolase decreased its adhesion to mice GI tissue disks to approximately 42 and $47 \%$ respectively, in relation to anti $\mathrm{His}_{6}$-CaYlr339cp (Figure 6A). The inhibition

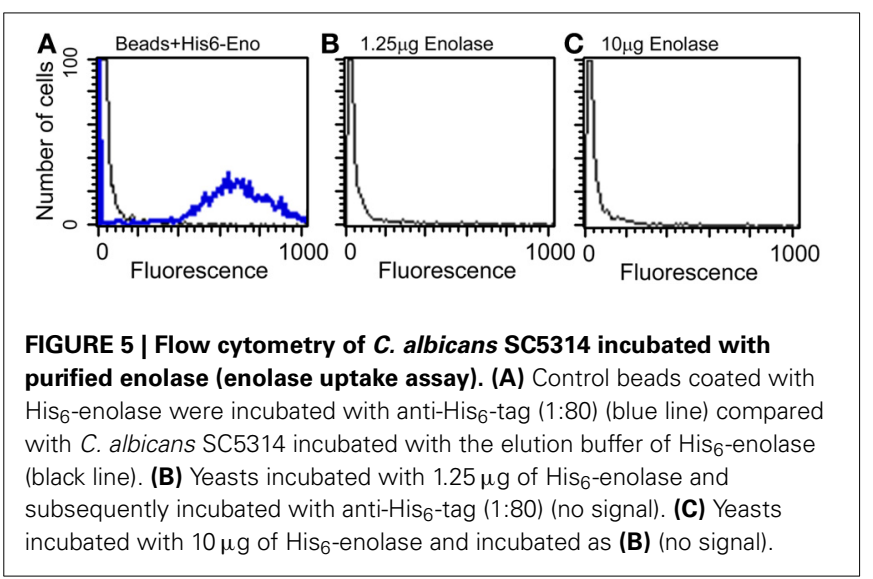

of adhesion seemed to saturate when $10 \mu \mathrm{g}$ of antibodies were used since twice of its concentration did not decrease proportionately the adhesion of yeasts to GI disks. In an attempt to verify if the decrease in adhesion observed was not due to the potential recognition and blockage of surface proteins rich in histidine regions in C. albicans, yeasts were also blocked with a monoclonal anti-His 6 -Tag antibody. There was no difference in adhesion in relation to the negative control (Data not shown). Also, viability assays indicated that this inhibition was not dependent on potential candidacidal activities promoted by the polyclonal antiserum raised against recombinant enolase (Figure S2 supplemental). These results indicate that the blockage of enolase present on the cell surface of $C$. albicans with specific antibodies against enolase impairs its adhesion to mice GI disks in vitro.

\section{INHIBITION OF C. albicans ADHESION TO MICE GI TISSUE DISKS BY PURIFIED RECOMBINANT ENOLASE}

Since the coating of cell surface enolase with antibodies was able to inhibit C. albicans yeasts adhesion to GI disks in vitro, we hypothesized that blocking potential enolase receptors on disks might also have an effect on $C$. albicans adhesion. To test this hypothesis, mice GI tissue disks were pre-incubated with different concentrations of recombinant $\mathrm{His}_{6}$-enolase. After incubation, disks were washed and then incubated with $C$. albicans yeasts. Strikingly, the incubation of disks with $0.5 \mathrm{mg}$ of soluble purified His $_{6}$-enolase inhibited C. albicans adhesion to GI disks at $70 \%$ in comparison to the purified protein $\mathrm{His}_{6}-\mathrm{CaYlr} 339 \mathrm{cp}$, used as a negative control. The decreased adhesion was dose dependent because incubation of disks with 0.1 and $0.2 \mathrm{mg}$ of enolase inhibited adhesion in 39 and $52 \%$ respectively (Figure 6B). There was no difference in the number of attached $C$. albicans cells per disk in relation to disks incubated with $\mathrm{His}_{6}-\mathrm{CaYlr339cp} \mathrm{in} \mathrm{PBS} \mathrm{or}$ PBS alone. Together, these results indicate that recombinant enolase may be blocking specific host enolase receptor(s) on mice GI disks, thus inhibiting the adhesion of C. albicans.

\section{DISCUSSION}

We identified enolase in C. albicans biofilms by mass spectrometry of SDS-PAGE bands in an initial attempt to study biofilm composition (data not shown). Using western blot and confocal microscopy we confirmed this observation and also identified for 

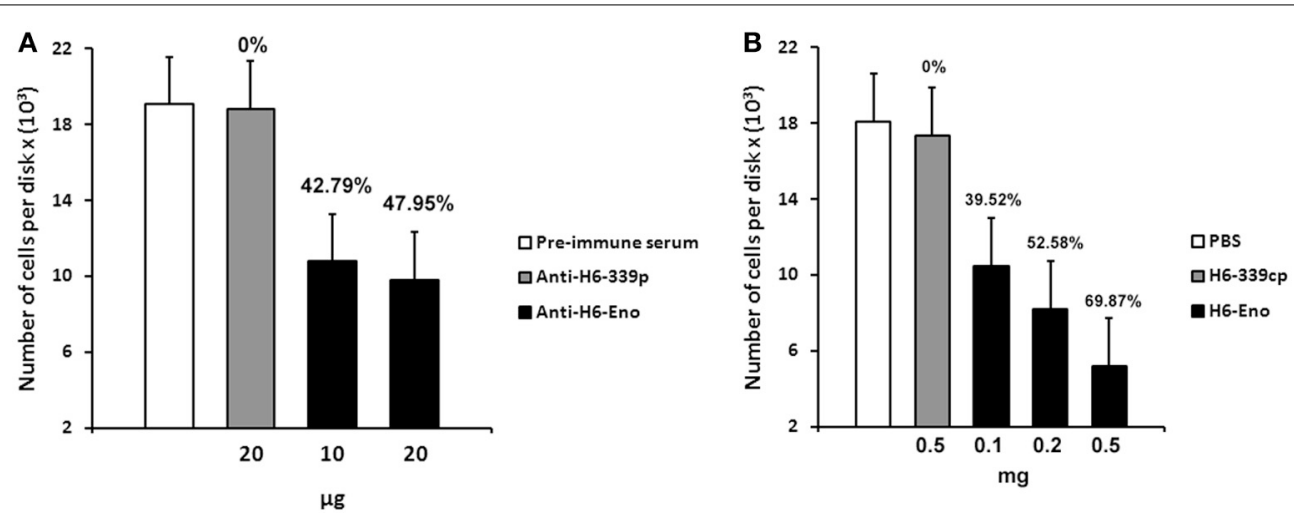

FIGURE 6 | Inhibition of $C$. albicans adhesion to mice gastrointestinal (GI) tissue disks. (A) Preincubation of C. albicans yeasts strain SC5314 with different concentrations of purified polyclonal anti His6-enolase (10 and $20 \mu \mathrm{g}$ ) inhibited its adhesion to $\mathrm{Gl}$ disks in comparison with the

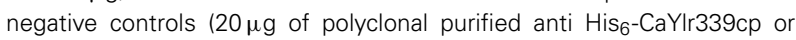
pre-immune serum). Data represent mean number of cells per tissue disks $\times\left(10^{3}\right)$ based on colony-forming units (cfu) counting of three independent experiments performed in triplicate. Bars represent the standard error (SE) of the means. Percentage values above the bars represent the percentage inhibition of adhesion with the negative control (anti $\mathrm{His}_{6}-\mathrm{CaY}$ Ir339cp) considered as 0\%. (B) Pretreatment of disks with increasing concentrations of the recombinant protein $\mathrm{His}_{6}$-enolase $(0.1-0.5$ $\mathrm{mg}$ ) inhibited $C$. albicans strain SC5314 adhesion in a dose dependent manner in comparison with the negative controls (disk incubated with $0.5 \mathrm{mg}$ of $\mathrm{His}_{6}-\mathrm{CaY}$ Ir339cp in PBS or PBS alone). Data represent mean number of cells per tissue disks $\times\left(10^{3}\right)$ based on colony-forming units (cfu) counting of three independent experiments performed in triplicate. Bars represent the standard error (SE) of the means. Percentage values above the bars represent the percentage inhibition of adhesion with the negative control ( $\mathrm{His}_{6}-\mathrm{CaY} / \mathrm{r} 339 \mathrm{cp}$ ) considered as $0 \%$. the first time enolase in biofilm forming cells, buds and growing hyphae of $C$. albicans (Figures 1-3). In its cytosolic form, enolase is a protein of approximately $48 \mathrm{kDa}$, which catalyzes the dehydration of 2-phosphoglycerate to generate phosphoenolpyruvate in the glycolytic pathway and the reverse reaction in gluconeogenesis (Sundstrom and Aliaga, 1992) but its function in the biofilm, whether structural or regulatory, is still unknown. Our results confirmed previous studies demonstrating enolase in biofilms (Thomas et al., 2006) and in planctonic cells (Angiolella et al., 1996), and provided for the first time evidence of extracellular enolase in biofilm forming cells and hyphae. Interestingly, enolase seems to migrate with a slightly larger molecular weight in the biofilm matix relative to the enolase detected in whole cell extracts of C. albicans, suggesting that enolase is being post-translationally modified in the biofilm. Further studies are necessary to address this question. Our FACS analysis and immunoblots of conditioned media suggested that enolase presence within the extracellular milieu is probably functional and not artifactual, e.g., by lysis of dead cells (Figures 2, 4, 5). To address the function of the extracellular enolase we devised adhesion assays using yeasts coated with anti-enolase antibodies and mice GI disks coated with purified enolase. Our results clearly show an important effect of inhibition in both types of experiments. These assays are a modification of the assay described by Segal and Sandovskylosica (1995), and was carried out using mice small intestine tissue disks, comprising the duodenum, jejunum and ileum. Because no differences in adhesion were observed among three equal portions of the small intestine (Figure S1 supplemental), the whole small intestine portion was used in all experiments herein. These assays allowed us to demonstrate how preincubation of disks with enolase and of $C$. albicans with anti-enolase antibodies block the adhesion. The intestinal serosa comprise a large portion of the intestinal disks, therefore it could be argued that $C$. albicans would also adhere to this portion. However, it was previously demonstrated that yeasts preferentially attach to the mucosa and only a limited number of organisms attach to the serosa, making this technique a much more realistic in vitro model to the actual in vivo phenomenon of attachment (Sandovskylosica and Segal, 1989).

Inhibition of C. albicans adhesion is one of the most well documented activities mediated by antibodies, and distinct levels of inhibitions toward many cell wall antigens have already been described (Cotter et al., 1998; Laforce-Nesbitt et al., 2008). In this work, we demonstrated a role for cell surface enolase in adhesion by blocking $C$. albicans with a specific anti-enolase antibody. We found that neutralization of cell surface enolase inhibits its adhesion to mice GI tissue disks. The saturation of inhibition observed indicates that multiple $C$. albicans molecules mediate the adhesion to gastrointestinal disks in vitro. Our experiments also show that these results were not biased by possible direct candidacidal activity of antibodies (Figure S2 supplemental) or by the induction of germ tubes formation by antiserum or by contact with tissue disks in vitro (data not shown). The decrease in adhesion by anti-enolase antibodies is not without precedent. Blocking of cell surface enolase from Paracoccidioides brasiliensis (Donofrio et al., 2009), and Streptococcus suis (Esgleas et al., 2008) inhibited their adhesion to pulmonary epithelial and brain microvascular endothelial cells respectively.

To further characterize the role of enolase on adhesion, mice GI tissue disks were incubated with recombinant enolase in an attempt to mask possible receptor binding sites on host tissues. Pretreatment of GI disks strongly inhibited C. albicans adhesion in a dose-dependent manner (Figure 6B). Incubation of C. albicans with the recombinant enolase indicated that the inhibition observed is not a consequence of possible cytotoxic contaminants 
on the purified protein (data not shown). An important inhibition of $C$. albicans adhesion was also observed by Segal and Savage after pretreatment of mice duodenal disks with chitin soluble extracts (Segal and Savage, 1986). Our data are in line with a previous study reporting a decrease in adhesion of S. suis, serotype two, to epithelial cells exposed to recombinant enolase (Zhang et al., 2009). Altogether these results suggest that enolase directly interacted to specific epithelial receptors on mice intestinal disks, thus inhibiting C. albicans adhesion.

The intestinal mucosa comprises an epithelial layer arranged in individual columns. It is composed of two fractions: a loosely adherent layer easily removable by suction and a layer firmly attached to the mucosa, which actually constitutes the intestinal epithelial cells glycocalyx (Hecht, 1999; Scott and Hancock, 2000; Atuma et al., 2001). C. albicans can associate directly to epithelium cells or to the mucus layer covering these cells (Kennedy et al., 1987). In view of this fact and the report showing the association of Streptococcus mutans enolase to a highly glycoysylated oral mucin in vitro (Ge et al., 2004), it is possible to speculate that enolase could be binding to glycoproteins covering the epithelium or even to loosely adherent mucus, therefore inhibiting C. albicans adhesion. However, we do not exclude the possibility that enolase might have inhibited the adhesion by modifying mucosal properties or host receptors (Freter and Jones, 1983), rendering Candida cells unable to bind to intestinal disks. Further research is required to determine the specific host receptor(s) involved in such interaction. Since the adherence of $C$. albicans to different surfaces is paramount for biofilm formation, it is possible that enolase expressed on the surface of biofilm-forming cells could also contribute to the adhesion of $C$. albicans to different substrates with potential implications for biofilm adhesion and formation. Further experiments are required to test this hypothesis. Nevertheless, based on our data, we propose that the $C$. albicans enolase present on the cell surface is functional and does not represent an artifact. We also propose that surface enolase plays an important role in adhesion of $C$. albicans in its major translocation site. Also, because enolase is encoded by a single gene in C. albicans genome, its dual role as a glycolytic enzyme and as an extracellular component, exemplifies an interesting and novel case of gene sharing in fungi.

\section{AUTHOR CONTRIBUTIONS}

Richard C. Silva, Ana Carolina B. Padovan, and Renata C. Ferreira conceived, performed and analyzed the data. Richard C. Silva, Ana Carolina B. Padovan and Marcelo R. S. Briones wrote the paper. Daniel C. Pimenta performed the preliminary mass spectra analysis of biofilms. Claudio V. da Silva helped to perform the immunofluorescence microscopy and flow cytometry experiments. Marcelo R. S. Briones conceived the experiments and supervised first authors. All authors analyzed the data and revised the final manuscript.

\section{ACKNOWLEDGMENTS}

We thank Dr. Renato A. Mortara for valuable help with microscopy and Paloma Hernandez for technical assistance. Richard C. Silva and Ana Carolina B. Padovan received MSc and PhD fellowships from Coordenação de Pessoal de Nível Superior
(CAPES), Brazil. Renata C. Ferreira is a postdoctoral fellow supported by Fundação de Amparo à Pesquisa do Estado de São Paulo (FAPESP) Brazil. Marcelo R. S. Briones received grants from FAPESP and $\mathrm{CNPq}$, Brazil. Parts of this work were conducted by Daniel C. Pimenta at the CAT/CEPID, a FAPESP program.

\section{SUPPLEMENTARY MATERIAL}

The Supplementary Material for this article can be found online at: http://www.frontiersin.org/journal/10.3389/fcimb. 2014.00066/abstract

\section{REFERENCES}

Angiolella, L., Facchin, M., Stringaro, A., Maras, B., Simonetti, N., and Cassone, A. (1996). Identification of a glucan-associated enolase as a main cell wall protein of Candida albicans and an indirect target of lipopeptide antimycotics. J. Infect. Dis. 173, 684-690. doi: 10.1093/infdis/173.3.684

Atuma, C., Strugala, V., Allen, A., and Holm, L. (2001). The adherent gastrointestinal mucus gel layer: thickness and physical state in vivo. Am. J. Physiol. Gastrointest. Liver Physiol. 280, G922-G929.

Bradford, M. M. (1976). A rapid and sensitive method for the quantitation of microgram quantities of protein utilizing the principle of protein-dye binding. Anal. Biochem. 72, 248-254. doi: 10.1016/0003-2697(76)90527-3

Carneiro, C. R. W., Postol, E., Nomizo, R., Reis, L. F. L., and Brentani, R. R. (2004). Identification of enolase as a laminin-binding protein on the surface of Staphylococcus aureus. Microb. Infect. 6, 604-608. doi: 10.1016/j.micinf.2004.02.003

Castaldo, C., Vastano, V., Siciliano, R. A., Candela, M., Vici, M., Muscariello, L., et al. (2009). Surface displaced alfa-enolase of Lactobacillus plantarum is a fibronectin binding protein. Microb. Cell Fact. 8, 14-23. doi: 10.1186/14752859-8-14

Colina, A. R., Aumont, F., Deslauriers, N., Belhumeur, P., and Derepentigny, L. (1996). Evidence for degradation of gastrointestinal mucin by Candida albicans secretory aspartyl proteinase. Infect. Immun. 64, 4514-4519.

Cotter, G., Weedle, R., and Kavanagh, K. (1998). Monoclonal antibodies directed against extracellular matrix proteins reduce the adherence of Candida albicans to HEp-2 cells. Mycopathologia 141, 137-142. doi: 10.1023/A:1006940203962

Dalle, F., Wachtler, B., L'ollivier, C., Holland, G., Bannert, N., Wilson, D., et al. (2010). Cellular interactions of Candida albicans with human oral epithelial cells and enterocytes. Cell. Microbiol. 12, 248-271. doi: 10.1111/j.14625822.2009.01394.x

Donofrio, F. C., Calil, A. C. A., Miranda, E. T., Almeida, A. M. F., Benard, G., Soares, C. P., et al. (2009). Enolase from Paracoccidioides brasiliensis: isolation and identification as a fibronectin-binding protein. J. Med. Microbiol. 58, 706-713. doi: 10.1099/jmm.0.003830-0

Eroles, P., Sentandreu, M., Elorza, M. V., and Sentandreu, R. (1997). The highly immunogenic enolase and Hsp70p are adventitious Candida albicans cell wall proteins. Microbiology 143, 313-320. doi: 10.1099/00221287143-2-313

Esgleas, M., Li, Y. Y., Hancock, M. A., Harel, J., Dubreuil, J. D., and Gottschalk, M. (2008). Isolation and characterization of alpha-enolase, a novel fibronectinbinding protein from Streptococcus suis. Microbiology 154, 2668-2679. doi: 10.1099/mic.0.2008/017145-0

Freter, R., and Jones, G. W. (1983). Models for studying the role of bacterial attachment in virulence and pathogenesis. Rev. Infect. Dis. 5, S647-S658. doi: 10.1093/clinids/5.Supplement_4.S647

Ge, J. P., Catt, D. M., and Gregory, R. L. (2004). Streptococcus mutans surface alphaenolase binds salivary mucin MG2 and human plasminogen. Infect. Immun. 72, 6748-6752. doi: 10.1128/IAI.72.11.6748-6752.2004

Hawser, S. P., and Douglas, L. J. (1994). Biofilm formation by candida species on the surface of catheter materials in-vitro. Infect. Immun. 62, 915-921.

Hecht, G. (1999). Innate mechanisms of epithelial host defense: spotlight on intestine. Am. J. Physiol. Cell Physiol. 277, C351-C358.

Holland, M. J., and Holland, J. P. (1978). Isolation and identification of yeast messenger ribonucleic-acids coding for enolase, glyceraldehyde-3-phosphate dehydrogenase, and phosphoglycerate kinase. Biochemistry 17, 4900-4907. doi: 10.1021/bi00616a007 
Iida, H., and Yahara, I. (1985). Yeast heat-shock protein of $\mathrm{Mr} 48,000$ is an isoprotein of enolase. Nature 315, 688-690. doi: 10.1038/315688a0

Ito, K., Ishiguro, A., Kanbe, T., Tanaka, K., and Torii, S. (1995). Detection of IgE antibody against Candida albicans enolase and its crossreactivity to Saccharomyces cerevisiae enolase. Clin. Exp. Allergy 25, 522-528. doi: 10.1111/j.1365-2222.1995.tb01089.x

Jong, A. Y., Chen, S. H. M., Stins, M. F., Kim, K. S., Tuan, T. L., and Huang, S. H. (2003). Binding of Candida albicans enolase to plasmin(ogen) results in enhanced invasion of human brain microvascular endothelial cells. J. Med. Microbiol. 52, 615-622. doi: 10.1099/jmm.0.05060-0

Kennedy, M. J., Volz, P. A., Edwards, C. A., and Yancey, R. J. (1987). Mechanisms of association of Candida albicans with intestinal mucosa. J. Med. Microbiol. 24, 333-341. doi: 10.1099/00222615-24-4-333

Laemmli, U. K. (1970). Cleavage of structural proteins during the assembly of the head of bacteriophage T4. Nature 227, 680-685. doi: 10.1038/227680a0

Laforce-Nesbitt, S. S., Sullivan, M. A., Hoyer, L. L., and Bliss, J. M. (2008). Inhibition of Candida albicans adhesion by recombinant human antibody single-chain variable fragment specific for Als3p. FEMS Immunol. Med. Microbiol. 54, 195-202. doi: 10.1111/j.1574-695X.2008.00465.x

Nucci, M., and Anaissie, E. (2001). Revisiting the source of candidemia: skin or gut? Clin. Infect. Dis. 33, 1959-1967. doi: 10.1086/323759

Odds, F. C., Webster, C. E., Mayuranathan, P., and Simmons, P. D. (1988). Candida concentrations in the Vagina and their association with signs and symptoms of vaginal candidosis. J. Med. Vet. Mycol. 26, 277-283. doi: 10.1080/02681218880000391

Padovan, A. C., Chaves, G. M., Colombo, A. L., and Briones, M. R. (2009). A novel allele of HWP1, isolated from a clinical strain of Candida albicans with defective hyphal growth and biofilm formation, has deletions of Gln/Pro and Ser/Thr repeats involved in cellular adhesion. Med. Mycol. 47, 824-835. doi: $10.3109 / 13693780802669574$

Pancholi, V. (2001). Multifunctional alpha-enolase: its role in diseases. Cell. Mol. Life Sci. 58, 902-920. doi: 10.1007/PL00000910

Piatigorsky, J. (2003). Crystallin genes: specialization by changes in gene regulation may precede gene duplication. J. Struct. Funct. Genomics 3, 131-137. doi: 10.1023/A:1022626304097

Sambrook J., Fritschi E. F., and Maniatis, T. (1989). Molecular Cloning: A Laboratorymanual. New York, NY: Cold Spring Harbor Laboratory Press.

Sandovskylosica, H., and Segal, E. (1989). Interaction of Candida-albicans with murine gastrointestinal mucosa - effect of irradiation on adherence invitro. J. Med. Vet. Mycol. 27, 345-352. doi: 10.1080/02681218980000471

Scott, M. G., and Hancock, R. E. W. (2000). Cationic antimicrobial peptides and their multifunctional role in the immune system. Crit. Rev. Immunol. 20, 407-431. doi: 10.1615/CritRevImmunol.v20.i5.40

Segal, E., and Sandovskylosica, H. (1995). Adhesion and interaction of Candidaalbicans with mammalian-tissues in-vitro and in-vivo. Adhes. Microb. Pathog. 253, 439-452. doi: 10.1016/S0076-6879(95)53038-X

Segal, E., and Savage, D. C. (1986). Adhesion of Candida albicans to mouse intestinal mucosa in vitro: development of the assay and test of inhibitors. J. Med. Vet. Mycol. 24, 477-479. doi: 10.1080/02681218680000751

Senet, J. M. (1997). Risk factors and physiopathology of candidiasis. Rev. Iberoam. Micol. 14, 6-13.
Strockbine, N. A., Largen, M. T., Zweibel, S. M., and Buckley, H. R. (1984). Identification and molecular weight characterization of antigens from Candida albicans that are recognized by human sera. Infect. Immun. 43, 715-721.

Sundstrom, P., and Aliaga, G. R. (1992). Molecular cloning of cDNA and analysis of protein secondary structure of Candida albicans enolase, an abundant, immunodominant glycolytic enzyme. J. Bacteriol. 174, 6789-6799.

Sundstrom, P., Jensen, J., and Balish, E. (1994). Humoral and cellular immune responses to enolase after alimentary tract colonization or intravenous immunization with Candida albicans. J. Infect. Dis. 170, 390-395. doi: 10.1093/infdis/170.2.390

Thomas, D. P., Bachmann, S. P., and Lopez-Ribot, J. L. (2006). Proteomics for the analysis of the Candida albicans biofilm lifestyle. Proteomics 6, 5795-5804. doi: 10.1002/pmic.200600332

Towbin, H., Staehelin, T., and Gordon, J. (1979). Electrophoretic transfer of proteins from polyacrylamide gels to nitrocellulose sheets: procedure and some applications. Proc. Natl. Acad. Sci. U.S.A. 76, 4350-4354. doi: 10.1073/pnas.76.9.4350

Tracy, M. R., and Hedges, S. B. (2000). Evolutionary history of the enolase gene family. Gene 259, 129-138. doi: 10.1016/S0378-1119(00)00439-X

Voss, A., Hollis, R. J., Pfaller, M. A., Wenzel, R. P., and Doebbeling, B. N. (1994). Investigation of the sequence of colonization and candidemia in nonneutropenic patients. J. Clin. Microbiol. 32, 975-980.

Walsh, T. J., Hathorn, J. W., Sobel, J. D., Merz, W. G., Sanchez, V., Maret, S. M., et al. (1991). Detection of circulating candida enolase by immunoassay in patients with cancer and invasive candidiasis. N. Engl. J. Med. 324, 1026-1031. doi: 10.1056/NEJM199104113241504

Zhang, A., Chen, B., Mu, X., Li, R., Zheng, P., Zhao, Y., et al. (2009). Identification and characterization of a novel protective antigen, enolase of Streptococcus suis serotype 2. Vaccine 27, 1348-1353. doi: 10.1016/j.vaccine. 2008.12.047

Conflict of Interest Statement: The authors declare that the research was conducted in the absence of any commercial or financial relationships that could be construed as a potential conflict of interest.

Received: 27 February 2014; accepted: 06 May 2014; published online: 03 June 2014. Citation: Silva RC, Padovan ACB, Pimenta DC, Ferreira RC, da Silva CV and Briones MRS (2014) Extracellular enolase of Candida albicans is involved in colonization of mammalian intestinal epithelium. Front. Cell. Infect. Microbiol. 4:66. doi: 10.3389/ fcimb.2014.00066

This article was submitted to the journal Frontiers in Cellular and Infection Microbiology.

Copyright (c) 2014 Silva, Padovan, Pimenta, Ferreira, da Silva and Briones. This is an open-access article distributed under the terms of the Creative Commons Attribution License (CC BY). The use, distribution or reproduction in other forums is permitted, provided the original author(s) or licensor are credited and that the original publication in this journal is cited, in accordance with accepted academic practice. No use, distribution or reproduction is permitted which does not comply with these terms. 